ISSN: 2224-0616

Int. J . Agril. Res. Innov. \& Tech. 4 (1): 1-10, June, 2014

Available online at http:// www.ijarit.webs.com

\title{
THE CONTRIBUTION OF TURMERIC RESEARCH AND DEVELOPMENT IN THE ECONOMY OF BANGLADESH: AN EX-POST ANALYSIS
}

\author{
M.K. Hasan ${ }^{*}$ and M.A.A. Mahmud ${ }^{2}$
}

Received 3 November 2013, Revised 28 May 2014, Accepted 28 June 2014, Published online 30 June 2014

\begin{abstract}
The study estimated the benefit and rates of returns to investment on turmeric research and development in Bangladesh. The Economic Surplus Model with ex-post analysis was used to determine the returns to investment and their distribution between the production and consumption. Several discounting techniques were also used to assess the efficiency of turmeric research. The adoption rate was found increasing trend over the period. The yield of BARI developed modern varieties of turmeric was 41 to $73 \%$ higher than those of the local variety. Society got net benefit Tk. 9333.88 million from the investment of turmeric research and extension. The net present value (NPV) and present value of research cost (PVRC) were estimated at Tk. 1200.84 and 157.88, respectively. The internal rate of return (IRR) and benefit cost ratio (BCR) were estimated to be $68 \%$ and 10.45 , respectively indicated investment on turmeric research and development was a good and profitable investment. Seed production programme of turmeric should be taken largely to increase production by increasing area adoption.
\end{abstract}

Keywords: Turmeric, Contribution, Adoption, Yield Advantage, Benefit and Rate of Return

${ }^{1}$ Senior Scientific Officer (Agricultural Economics), Spices Research Centre, Bangladesh Agricultural Research Institute, Shibgonj, Bogra, Bangladesh

${ }^{2}$ Assistant Inspector General (Crime-East), Bangladesh Police, Police Headquarter, Dhaka, Bangladesh

*Corresponding author's email: kamrulspc@yahoo.com (M.K. Hasan)

\section{Introduction}

Turmeric is a spice derived from the rhizome of Curcuma longa L. which is used as condiment, flavouring and colouring agent, drug and cosmetic in addition to its use in social and religious ceremonies. It is a principal ingredient in the Bangladeshi kitchen as curry powder and paste. It adds flavour and colour to curries and has medicinal values also. In 1984-85, just before development and introducing of improved varieties of turmeric in Bangladesh yield per hectare was very low and it was only 1.92 tonnes per hectare. Yield per hectare of turmeric started to increase since 1985-86 and it stands 5.16 tonnes per hectare in 2007-08 production period, due to develop and dissemination of improved varieties of turmeric (BBS, 2012).

Due to increasing population, demand for cereal food increased significantly. To mitigate this demand, the land of turmeric crops is being diverted to cereal food crop cultivation. On the other hand, now-a-days many spice-processing industries such as Square, BD Foods, Pran, Archu, Advanced Chemical Industries (ACI), Amrita, Dekko etc. have been established in Bangladesh. They are exporting turmeric as a finished product outside the country. Due to that, demands for turmeric as raw material of these industries are increasing with the extension of their production. That is why; the total demands for turmeric are increasing at incremental rate. Resulting that, a big gap was observed between production and demand now. To meet up this gap the country has to spend a huge amount of foreign currency in every year for importing spices from abroad.

Realizing the importance of turmeric, Bangladesh government started turmeric research through Horticulture Division of BARI since 1980-81 for increasing turmeric production. But the fund was not sufficient to do research vastly. To keep the continuity of research of turmeric and other spices, Bangladesh government established Spices Research Centre (SRC) in 1994 under Bangladesh Agricultural Research Institute (BARI) for increasing the production of turmeric throughout the country. BARI has already released three improved turmeric varieties namely BARI Turmeric- 1, 2, and 3. These varieties are cultivated in the farmers' fields since the release of these varieties. BARI, BARC (Bangladesh Agricultural Research Council) and DAE (Department of Agricultural Extension), to some extent have strengthened their works to turmeric production. However, for the research work of turmeric and its development, the contribution of BARC and DAE are greatly associated with BARI.

The present analysis thus took into the benefits from past turmeric research and its farm level development in the country. However, this study provided information for the policy makers, donors, researchers, extension people and the public on the contribution and the rate of return to investment in turmeric research in Bangladesh. 


\section{Methodology}

Sources of data

For the present study, data were collected from different sources like published and unpublished reports, and informal scientist's interview. The area, production and yield of BDMVs (BARI Developed Modern Varieties) of turmeric were collected from SRC (Spices Research Centre); adoption rates were collected through informal scientist's interview; and harvest price and consumer price index (CPI) were collected from various issues of Statistical Yearbooks (1985 to 2012) published by the Bangladesh Bureau of Statistics. The supply elasticity was taken from the study conducted by Dey and Norton (1993). Since SRC of BARI is the main organization for turmeric research, the research cost included mainly from SRC of BARI. The extension and promotion activities were done by DAE and the related costs were collected from this organization. BARC mainly provided the administrative costs. The on-farm yield data of BDMVs turmeric varieties were collected from the SRC, Bogra. Data on the input cost change was calculated by the researcher through analyzing increased production claimed higher labour costs for harvesting and transporting, expensive of seeds, and used slightly more fertilizers per hectare for improved variety than for traditional varieties.

\section{Analytical procedure}

The collected data were analyzed using the following statistical techniques.

Estimation of returns to investment

The Economic Surplus Model (ESM) with Ex-Post analysis was used to estimate the rate of returns to investment in turmeric research and extension. The analysis was done under small open-economy market situation. The theoretical concept of ESM has been illustrated below.

Theoretical concept of Economic Surplus Model (ESM): The concept of economic surplus was used to measure economic welfare and the changes in economic welfare from policy and other interventions (Alston et al., 1995; Currie et al., 1971). Usually the economic surplus concept is adopted to estimate the benefits from the adoption of improved varieties. The components of economic surplus are consumer surplus and producer surplus. Given the initial condition (i.e., pre-research supply curve $S_{1}$ and demand curve $\left.D_{1}\right)$, consumer surplus is depicted as Area $\mathrm{P}_{0} \mathrm{P}_{\mathrm{n}} \mathrm{b}$ in Fig. 1. This is the surplus or benefit to consumers because of a functioning market. Consumer surplus is that area beneath the demand curve less the cost of consumption. The cost of consumption is the area below the price line $\mathrm{P}_{\mathrm{n}}$. Producer surplus is defined by area $\mathrm{P}_{n} \mathrm{bO}$ in Fig. 1. Area $\mathrm{P}_{\mathrm{n}} \mathrm{bO}$ in the surplus left to the farmers after they have paid for the total costs of production, area ObQ (Alston et al., 1995).

The adoption of an intervention by farmers, such as an improved variety usually means one of two things: (i) A farmer can supply more of the commodity using the same level of resources (i.e, same land area and other inputs), or (ii) A farmer can supply the same level of commodity output but do it with fewer resources.

In either case, this is depicted by a shift to the right of the supply curve as shown in Fig. 1 (the shift is from $S_{1}$ to $S_{2}$ ). The shift is the supply curve from the adoption of an intervention changes the initial equilibrium price and quantity of the commodity. This new price quantity equilibrium increases economic surplus. The change in economic surplus (economic benefits) is measured by comparing the difference in economic surplus between the pre-adoption period and the post-adoption period.

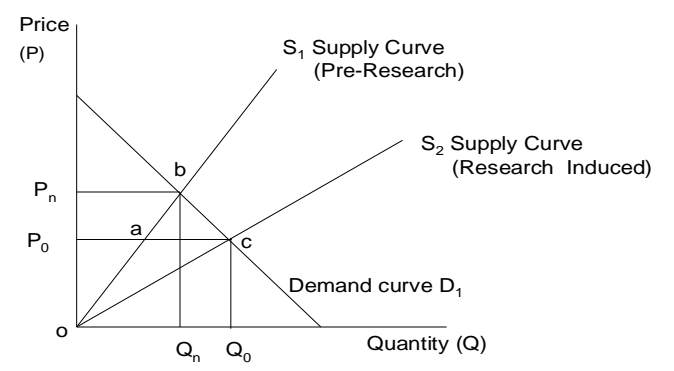

Change in Consumer Surplus = Area abc + Area $\mathrm{P}_{n} b_{a} P_{o}$ Change in Producer Surplus = Area Oac-Area $\mathrm{P}_{n}$ baPo Change in Total Economic Surplus = Area abc+Area Oac

Fig. 1. Economic Surplus Model (Closed Economy) Given a shift in the supply curve $S_{1}$ to $S_{2}$, the change in consumer surplus is depicted in Fig. 1 as Area abc + Area $\mathrm{P}_{n} b_{a} P_{0}$. The shift in the supply curve (due to the adoption of an intervention) has decreased the price consumers now have to pay for the commodity.

Given a shift in the supply curve $S_{1}$ to $S_{2}$, the change in producer surplus is depicted in Fig.1 as Area Oac-Area $\mathrm{P}_{\mathrm{n}} \mathrm{baP}_{0}$. Area Oac represents the decrease in the cost of production the same unit of the commodity that farmers now enjoy because they are using the intervention. This represents the benefits to the farmers from adopting the intervention and can be measured and quantified in monetary terms. The adoption of the intervention, however, has increased the quantity produced thereby decreasing the price of the commodity ( $\mathrm{P}_{\mathrm{n}}$ to $\mathrm{P}_{0}$ in Fig. 1 ) and is a loss to farmers income. Farmers can recover some of this loss since they can sell more quantity $\left(Q_{n}\right.$ to $\mathrm{Q}_{0}$ in Fig. 1) of the commodity.

The total social benefits to society from the adoption of an intervention is the summation of the change in consumer surplus plus the change in producer surplus (Area abc + Area Oac) minus the input cost change from adopting the new interventions.

For a closed economy model, the estimated price elasticity of demand is used in the above formulas. For small open-economy model where the elasticity of demand is perfectly elastic, use a sufficiently large number of $\eta$ (Nagy and Alam, 
2000). A small open economy market is one where the amount of exports or imports is small relative to total world trade in the commodity. Thus, there is little or no effect on the world price of the commodity (the small country assumption). In this case, the price of commodity does not change with the shift in the supply curve. For this study, the Bangladesh turmeric market is modelled as a small open economy market.

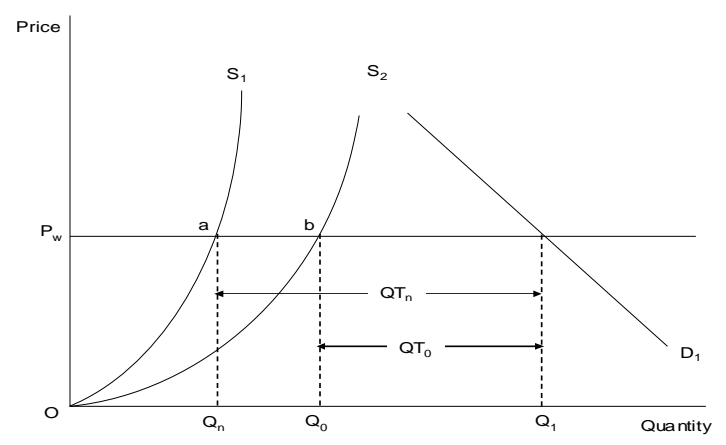

Fig. 2. Small Open-economy Importer Economic Surplus Model

The change in economic surplus for a small openeconomy that is domestically produced but allows imports to cover shortfall (i.e., the Bangladesh turmeric market) is depicted Fig. 2. The world price $\mathrm{P}_{\mathrm{w}}$ and quantity demanded by Bangladeshi consumers $\mathrm{Q}_{1}$ defines the initial equilibrium. At price $\mathrm{P}_{\mathrm{w}}$, producers supply $\mathrm{Q}_{\mathrm{n}}$ amount of turmeric when faced by the pre-research supply curve $\mathrm{S}_{1}$. Turmeric imports are equal to $\mathrm{QT}_{\mathrm{n}}$. When faced by the research induced supply curve $S_{2}$ (the supply curve that exist because farmers have adopted new high yielding varieties). Turmeric producers increased production to quantity $\mathrm{Q}_{n}$ and increase $\mathrm{Q}_{\mathrm{n}} \mathrm{Q}_{0}$. Spices imports are decreased by the same amount as the increase in production $\mathrm{Q}_{\mathrm{n}} \mathrm{Q}_{0}$ and are now at $\mathrm{QT}_{0}$. Since $\mathrm{P}_{\mathrm{w}}$ does not change (small economy assumption), there is no change in consumer surplus- consumers are neither better off nor worse off. The enter change in economic surplus from the adoption of new turmeric varieties is thus a change in producer surplus only and is identified by area oab in Fig. 2 (corresponds to area oac in Fig. 1). The amount of foreign exchange saved by the adoption of improved varieties is equal to $\mathrm{P}_{\mathrm{w}} \mathrm{x}\left(\mathrm{Q}_{\mathrm{n}} \mathrm{Q}_{0}\right)$.

Empirical approach: The Akino and Hayami (1975) approximation formulas for calculating changes to producer and consumer economic surplus are described below and these are used in this study. The Akino and Hayami (1975) approximation formulas for calculating the change in economic surplus for a closed economy analysis (Fig. 1) is as follows:

$$
\begin{aligned}
& \text { Area A (abc) } \\
& \text { Area B (Oac) } \\
& =0.5 \mathrm{P}_{\mathrm{o}} \mathrm{Q}_{\mathrm{o}}\left((\mathrm{k}(1+\gamma))^{2} /(\gamma+\eta)\right) \\
& =\mathrm{kP}_{\mathrm{o}} \mathrm{Q}_{\mathrm{o}} \\
& =\left(\left(P_{0} Q_{0} k(1+\gamma)\right) /(\gamma+\eta)\right) \times(1-((0.5 k(1+\gamma) \eta) /(\gamma+\eta))-0.5 k(1+\gamma))
\end{aligned}
$$

Where,

$$
\begin{array}{ll}
\mathrm{P}_{\mathrm{o}} & =\text { Price of turmeric (Tk./ ton) (Existing market price) } \\
\mathrm{Q}_{\mathrm{o}} & =\text { Production of BDMVs turmeric (ton) (Existing production) } \\
\mathrm{P}_{\mathrm{n}} & =\text { Quantity price that would exist in absence of research } \\
\mathrm{Q}_{\mathrm{n}} & =\text { Quantity of the turmeric produced that would exist in absence of research } \\
\mathrm{k} & =\text { Horizontal supply shifter } \\
\mathrm{\gamma} & =\text { Price elasticity of turmeric supply } \\
\eta & =\text { Absolute price elasticity of the demand for the commodity. }
\end{array}
$$

The supply shifter ( $\mathrm{k}$ ): The supply shifter $\mathrm{k}$ ' is the from the equilibrium price $\mathrm{P}_{\mathrm{n}}$ given $\mathrm{S}_{1}$ to the overall yield advantage of improved varieties of turmeric over the local variety weighed by the area sown to the improved varieties of turmeric. In the case of the Akino and Hayami (1975) equilibrium price $P_{0}$ given $S_{2}$ which corresponds to a distance equal to $\mathrm{Q}_{\mathrm{n}} \mathrm{Q}_{\mathrm{o}}$ in Fig. 1 (Gardiner et al., 1986; Nagy and Furtan, 1978). approximation formulas, $\mathrm{k}$ is the horizontal shift The supply shifter $\mathrm{k}$ is calculated as follows:

Where,

$$
\left.k_{t}=\sum_{i=1}^{n}\left[1-\frac{Y_{t}}{Y_{i t}}\right)\right] \times A_{i t}
$$

$$
\begin{aligned}
& \text { Yit }=\text { Yield of theimprove varieties of turmeric in year t } \\
& \text { Yt }=\text { The yield of a base (or average yield of local variety turmeric) that has been gown in the past } \\
& \text { Ait }=\text { The that would still be grown if no new varieties had been developed } \\
& \mathrm{n}=\text { The number of improved turmeric varieties }
\end{aligned}
$$

\section{Estimation of net present value (NPV)}

The amount of total funds returned from the benefits were calculated by using the following investment in research is called NPV. The formula of NPV:

$$
\begin{aligned}
& N P V=\left[\sum_{i=1}^{n}\left(T S B_{t}-C_{t}\right)(1+r)^{-t}\right] \\
& \text { Where, } \\
& \begin{aligned}
\mathrm{Ct} & =\text { The cost of research and extension investment in year } \mathrm{t} \\
\mathrm{r} & =\text { The discount rate }
\end{aligned} \\
& \mathrm{n}=\text { The time horizon over which the benefits of the research investments are realized }
\end{aligned}
$$




\section{Internal rate of return (IRR)}

The IRR was calculated relating to the total social benefit (TSB) minus an input cost change, if any, in each year to the research expenditure (C) in each year and is the discount rate that results in a zero net present value of the benefits. The IRR is calculated as

$$
O=\left[\sum_{t=1}^{n}\left(T S B \quad-C_{t}\right)(1+\operatorname{IRR})^{-t}\right]
$$

The IRR can be defined as the rate of interest that makes the accumulated present value of the flow of costs equal to the discounted present value of the flow of returns, at a given point in time (Peterson, 1971).

\section{Results and Discussion}

Adoption status and yield advantages of BARI developed modern varieties of turmeric

The adoption of improved variety is very important factors by which the volume of change in economic surplus is determined. The more the adoption of improved varieties over traditional one, higher the change in surplus will be. Apart from this, it gives us feedback as to why and how well a technology is being accepted by the farmers. There was no turmeric varietal adoption survey conducted in Bangladesh. The existing variety survey information along with the considerable field experience of the spices scientists is used to sketch out the per centage area sown by variety grouping which are presented in Table 1.

Three modern varieties of turmeric named BARI Turmeric-1, BARI Turmeric-2 and BARI Turmeric-3 were released from BARI. BARI Turmeric-1, BARI Turmeric-2 were released in the same year 1984-85 but BARI Turmeric-3 was released in 1998-99. The overall area coverage of BARI Turmeric-1 increased from 0.50 per cent in 1985-86 to 22 per cent in 200708 but BARI Hodud-2 increased from 0.50 per cent to 21 per cent over the years. On the contrary of another modern variety BARI Turmeric- 3 , the area coverage increased from 1 per cent in 1999-2000 to 13 per cent in 2007-08. Area covered by all BDMVs of turmeric occupied about 56 per cent of the area sown to turmeric (Table 1).

Table 1 Area of traditional variety replaced by BMVs of turmeric

\begin{tabular}{|c|c|c|c|c|c|c|c|c|c|c|c|c|}
\hline \multirow[t]{2}{*}{ Year } & \multicolumn{2}{|c|}{$\begin{array}{l}\text { Total turmeric } \\
\text { area }\end{array}$} & \multicolumn{2}{|c|}{$\begin{array}{l}\text { Area of LVs } \\
\text { of turmeric }\end{array}$} & \multicolumn{2}{|c|}{$\begin{array}{c}\text { Area covered } \\
\text { by BARI } \\
\text { Turmeric-1 }\end{array}$} & \multicolumn{2}{|c|}{$\begin{array}{c}\text { Area covered } \\
\text { by BARI } \\
\text { Turmeric- } 2 \\
\end{array}$} & \multicolumn{2}{|c|}{$\begin{array}{c}\text { Area covered } \\
\text { by BARI } \\
\text { Turmeric-3 }\end{array}$} & \multicolumn{2}{|c|}{$\begin{array}{c}\text { Area covered } \\
\text { by all BMVs of } \\
\text { turmeric }\end{array}$} \\
\hline & ha & $\%$ & ha & $\%$ & ha & $\%$ & ha & $\%$ & ha & $\%$ & ha & $\%$ \\
\hline $1979-80$ & 13899 & 100 & 13899 & 100 & 0 & 0.00 & 0 & 0.00 & 0 & 0.00 & 0 & 0.00 \\
\hline 1980-81 & 14251 & 100 & 14251 & 100 & 0 & 0.00 & 0 & 0.00 & 0 & 0.00 & 0 & 0.00 \\
\hline 1981-82 & 14599 & 100 & 14599 & 100 & 0 & 0.00 & 0 & 0.00 & 0 & 0.00 & 0 & 0.00 \\
\hline 1982-83 & 14080 & 100 & 14080 & 100 & 0 & 0.00 & 0 & 0.00 & 0 & 0.00 & 0 & 0.00 \\
\hline $1983-84$ & 14162 & 100 & 14162 & 100 & 0 & 0.00 & 0 & 0.00 & 0 & 0.00 & 0 & 0.00 \\
\hline 1984-85 & 15049 & 100 & 15049 & 100 & 0 & 0.00 & 0 & 0.00 & 0 & 0.00 & 0 & 0.00 \\
\hline 1985-86 & 15202 & 100 & 15050 & 99 & 76 & 0.50 & 76 & 0.50 & 0 & 0.00 & 152 & 1.00 \\
\hline 1986-87 & 16160 & 100 & 15837 & 98 & 162 & 1.00 & 162 & 1.00 & 0 & 0.00 & 324 & 2.00 \\
\hline 1987-88 & 16051 & 100 & 15409 & 96 & 321 & 2.00 & 321 & 2.00 & 0 & 0.00 & 642 & 4.00 \\
\hline 1988-89 & 15773 & 100 & 14827 & 94 & 315 & 2.00 & 631 & 4.00 & 0 & 0.00 & 946 & 6.00 \\
\hline 1989-90 & 16372 & 100 & 15226 & 93 & 491 & 3.00 & 655 & 4.00 & 0 & 0.00 & 1146 & 7.00 \\
\hline 1990-91 & 16332 & 100 & 14699 & 90 & 817 & 5.00 & 817 & 5.00 & 0 & 0.00 & 1634 & 10.00 \\
\hline 1991-92 & 16285 & 100 & 14168 & 87 & 977 & 6.00 & 1140 & 7.00 & 0 & 0.00 & 2117 & 13.00 \\
\hline 1992-93 & 16089 & 100 & 13515 & 84 & 1287 & 8.00 & 1287 & 8.00 & 0 & 0.00 & 2574 & 16.00 \\
\hline 1993-94 & 16132 & 100 & 12906 & 80 & 1613 & 10.00 & 1613 & 10.00 & 0 & 0.00 & 3226 & 20.00 \\
\hline 1994-95 & 15986 & 100 & 12789 & 80 & 1758 & 11.00 & 1439 & 9.00 & 0 & 0.00 & 3197 & 20.00 \\
\hline 1995-96 & 16026 & 100 & 12500 & 78 & 1923 & 12.00 & 1603 & 10.00 & 0 & 0.00 & 3526 & 22.00 \\
\hline 1996-97 & 16132 & 100 & 12099 & 75 & 2097 & 13.00 & 1936 & 12.00 & 0 & 0.00 & 4033 & 25.00 \\
\hline 1997-98 & 16063 & 100 & 11887 & 74 & 2088 & 13.00 & 2088 & 13.00 & 0 & 0.00 & 4176 & 26.00 \\
\hline 1998-99 & 15846 & 100 & 11409 & 72 & 2218 & 14.00 & 2218 & 14.00 & 0 & 0.00 & 4436 & 28.00 \\
\hline 1999-00 & 15575 & 100 & 10591 & 68 & 2336 & 15.00 & 2492 & 16.00 & 156 & 1.00 & 4984 & 32.00 \\
\hline 2000-01 & 15800 & 100 & 9954 & 63 & 2686 & 17.00 & 2844 & 18.00 & 316 & 2.00 & 5846 & 37.00 \\
\hline 2001-02 & 16018 & 100 & 9611 & 60 & 3043 & 19.00 & 2723 & 17.00 & 641 & 4.00 & 6407 & 40.00 \\
\hline $2002-03$ & 15992 & 100 & 9275 & 58 & 2879 & 18.00 & 3038 & 19.00 & 800 & 5.00 & 6717 & 42.00 \\
\hline 2003-04 & 18441 & 100 & 9589 & 52 & 3688 & 20.00 & 3873 & 21.00 & 1291 & 7.00 & 8852 & 48.00 \\
\hline 2004-05 & 18939 & 100 & 9470 & 50 & 3977 & 21.00 & 3788 & 20.00 & 1705 & 9.00 & 9470 & 50.00 \\
\hline 2005-06 & 20413 & 100 & 9594 & 47 & 4083 & 20.00 & 4287 & 21.00 & 2450 & 12.00 & 10820 & 53.00 \\
\hline $2006-07$ & 21028 & 100 & 9673 & 46 & 4416 & 21.00 & 4626 & 22.00 & 2313 & 11.00 & 11355 & 54.00 \\
\hline 2007-08 & 22008 & 100 & 9684 & 44 & 4842 & 22.00 & 4622 & 21.00 & 2861 & 13.00 & 12325 & 56.00 \\
\hline
\end{tabular}

Source: Several issues of BBS

Note: BDMVs- BARI Developed Modern Varieties, LVs- Traditional Varieties and shaded area indicates no improved varieties were released. 
Table 2. Adoption rate of BARI developed modern varieties of turmeric

\begin{tabular}{lcc}
\hline Name of crop & Varietals Name & Adoption rate(\%) \\
\hline \multirow{3}{*}{ Turmeric } & BARI Turmeric-1(1985-86 to 2007-08) & 1.06 \\
& BARI Turmeric-2 (1985-86 to 2007-08) & 1.05 \\
& BARI Turmeric-3(1999-00 to 2007-08) & 1.58 \\
& Total BDMVs of turmeric (1985-86 to 2007-08) & 2.64 \\
\hline
\end{tabular}

The annual adoption rates were estimated to 1.06 per cent for BARI Turmeric-1 (1985-86 to 200708), 1.05 per cent for BARI Turmeric-2 (1985-86 to 2007-08) and 1.58 per cent for BARI Turmeric3 (1999-2000 to 2007-08) as depicted from Table 2. The adoption rate of BARI Turmeric- 3 was higher than those of BARI Turmeric- $1 \& 2$ due to attractive colour and higher yield. The table also showed that the adoption rate of all BDMVs of turmeric was 2.64 per cent.

Supply shifter $\mathrm{k}$

Table 3. Calculation of the supply shifter (K) of BARI Turmeric over traditional variety

\begin{tabular}{lcccc}
\hline Year & $\begin{array}{c}\text { \% Area BARI Turmeric-1 } \\
\text { replacing LVs }\end{array}$ & $\begin{array}{c}\text { \% Area BARI Turmeric-2 } \\
\text { replacing LVs }\end{array}$ & $\begin{array}{c}\text { \%Area BARI Turmeric-3 } \\
\text { replacing LVs }\end{array}$ & $\begin{array}{c}\text { Supply shifter } \\
\mathrm{k}\end{array}$ \\
\hline $1983-84$ & 0 & 0 & 0 & 0 \\
$1984-85$ & 0 & 0 & 0 & 0 \\
$1985-86$ & 0.5 & 0.5 & 0 & 0.0049 \\
$1986-87$ & 1 & 1 & 0 & 0.0099 \\
$1987-88$ & 2 & 2 & 0 & 0.0197 \\
$1988-89$ & 2 & 4 & 0 & 0.0279 \\
$1989-90$ & 3 & 4 & 0 & 0.0437 \\
$1990-91$ & 5 & 5 & 0 & 0.0633 \\
$1991-92$ & 6 & 7 & 0 & 0.0790 \\
$1992-93$ & 8 & 8 & 0 & 0.0987 \\
$1993-94$ & 10 & 10 & 0 & 0.1004 \\
$1994-95$ & 11 & 9 & 0 & 0.1103 \\
$1995-96$ & 12 & 10 & 0 & 0.1243 \\
$1996-97$ & 13 & 12 & 0 & 0.1283 \\
$1997-98$ & 13 & 13 & 0 & 0.1382 \\
$1998-99$ & 14 & 14 & 0 & 0.1595 \\
$1999-00$ & 15 & 16 & 1 & 0.1866 \\
$2000-01$ & 17 & 18 & 2 & 0.2087 \\
$2001-02$ & 19 & 17 & 4 & 0.2184 \\
$2002-03$ & 18 & 19 & 5 & 0.2528 \\
$2003-04$ & 20 & 21 & 7 & 0.2691 \\
$2004-05$ & 21 & 20 & 9 & 0.2894 \\
$2005-06$ & 20 & 21 & 12 & 0.2919 \\
$2006-07$ & 21 & 22 & 11 & 0.3082 \\
$2007-08$ & 22 & 21 & 13 & \\
\hline
\end{tabular}

Table 3 shows each year adoption per centage and supply shifter of turmeric. It was found that the rate of shift gradually increased. The shifter accounted for the yield advantage of BARI developed turmeric varieties over the traditional varieties. The supply shifter of turmeric was found to be 0.308 for the year 2007-08, meaning that $31 \%$ more turmeric production was made available during 2007-08 because of farmers' adoption of BARI developed turmeric variety.

Yield advantages: This is very important factor to determine the economic surplus. The higher yield advantage always ensures higher level of economic surplus. Two types of data exist in most
The supply shifter $\mathrm{k}$ identifies the amount of production that can be attributed to the varietals improvement research in each year (i.e., the shift in the supply curve). The more the value of supply shifter the more is the shift in the supply curve, resulting higher benefit to the society. The supply shifter is the outcome of the simultaneous force of adoption per centage and yield advantage. It was calculated using the formula discussed in methodology. of the less developed countries for good estimation of yield advantage (YA) as well as the aggregate production function shifter. They are on-station yield trial data and on-farm yield data. The on-station yield data is readily available and most often the only reliable source. One of the arguments against using on-station yield trial data is that of superior management practices and techniques are used and therefore, the results may not reflect on the on-farm situation. Another argument placed by different author (Hertford and Schmits, 1971; Ayer and Schuh, 1972; Akino and Hayami, 1975; Scobie and Posada, 1977; Nagy and Alam, 2000) and showed that the yield advantage estimation from 
the on-station yield trial data would be biased upward because the estimation might also include the contribution made by inputs such as fertilizer and water. To account for this problem, the estimated yield advantage of new varieties by estimating production functions of yield as a function of new varieties and other inputs. This process requires a substantial data which is not readily available in Bangladesh.

For the present study, on-farm yield trial data were considered as a more reliable source for the calculation of yield advantage rather than the onstation yield data in Bangladesh. The yield advantages have been calculated for this study following Gardiner et al. (1986), Nagy and Furtan (1978) and Nagy (1991).

Developed varieties of Spices Research Centre (SRC) of BARI have replaced the traditional varieties starting in 1985-86 for BARI Turmeric1 and BARI Turmeric-2 and 1999-00 for BARI Turmeric-3.

Table 4. Yield advantages of improved varieties of turmeric over traditional varieties

\begin{tabular}{lcccc}
\hline $\begin{array}{l}\text { Name of turmeric } \\
\text { crop }\end{array}$ & $\begin{array}{c}\text { Average (weighted) yield of } \\
\text { Improved variety (t/ha) }\end{array}$ & $\begin{array}{c}\text { Average yield of } \\
\text { traditional variety (t/ha) }\end{array}$ & $\begin{array}{c}\text { Yield difference } \\
\text { (t/ha) }\end{array}$ & $\begin{array}{c}\text { Yield } \\
\text { advantage }\end{array}$ \\
\hline BARI Turmeric-1 & 4.123 & 1.74 & 2.38 & 0.578 \\
BARI Turmeric-2 & 2.946 & 1.74 & 1.21 & 0.409 \\
BARI Turmeric-3 & 6.476 & 1.74 & 4.74 & 0.731 \\
\hline
\end{tabular}

The weighted yields were calculated by taking the average of the irrigated optimum, late irrigated and non irrigated yield multiplied by the mean of irrigated, late irrigated and non irrigated area of turmeric. Per hectare average yield of high yielding varieties of turmeric i.e. BARI Turmeric1,2 and 3 were found to be $4.12,2.95$ and 6.48 tonnes, respectively. In case of traditional variety it was only 1.74 tonnes. Therefore, the yield advantages of BARI Turmeric- 1,2 and 3 over traditional variety were found to be 58, 41 and $73 \%$, respectively (Table 4 ).

Estimating benefits from turmeric research and extension

This section deals with the estimation of returns to investment in turmeric research and extension using the economic surplus approach. This approach estimates the benefits to agricultural research by measuring the change in consumers' surplus (CS) and producers' surplus (PS) from a rightward shift in the supply curve that is brought about through technological change. It should be mentioned here that aggregate consumers' surplus, producers' surplus and total surplus were calculated by summing up corresponding surpluses of all turmeric rather than summing up from the areas of the model. In order to calculate the net benefits (NB) research and extension expenditures are subtracted from total surplus. All these estimates of benefits are expressed in real term by using 2007-08 constant prices. The rates of return and NB are then discounted using $10 \%$ interest rate for obtaining the efficiency of investment. First, the yearly total social benefits are estimated using the small-open economy model (Fig. 2).
This is done by assigning a very high number to the demand elasticity parameter ( $\mathrm{y}$ ) since in a small open-economy model, $\mathrm{y}$ is perfectly elastic. The analysis is undertaken for each year 1980-81 to 2007-08 for turmeric.

Turmeric research and extension in Bangladesh are seemed to be continued by three different organizations. The Organizations are Bangladesh Agricultural Research Institute (BARI), Bangladesh Agricultural Research Council (BARC) and Department of Agricultural Extension (DAE). The turmeric research and extension expenditure comprised the expenditure of three organizations are furnished in the following sequence.

The year wise expenditures behind variety development and dissemination for the new varieties to the farmers of turmeric are shown in Table 5. The expenditures of BARI/SRC and BARC were estimated from 1980-81 to 2007-08. The accumulated expenditures over the years of BARI/SRC and BARC were estimated at Tk. 95.88 and 17.71 million, respectively. Extension expenditures and input cost change were estimated after development of improved variety and they were started since 1985-86. The cumulative expenditures of extension and input cost changes were respectively amounted at Tk. 67.02 and 530.04 million. Over the years, expenditures accruing for BARI/SRC, BARC, DAE and input cost change were Tk. 710.65 million. For the analysis, the current total expenditures were converted to 2007-08 constant prices using the Bangladesh Middle Income Group CPI Index and it was Tk. 987.70. 
Table 5. Turmeric research and extension expenditures by sources from 1980-81 to 2007-08

\begin{tabular}{lcccccc}
\hline Year & $\begin{array}{c}\text { Total } \\
\text { BARI/ SRC } \\
\text { Research } \\
\text { Expenditures } \\
\text { (current Taka) }\end{array}$ & $\begin{array}{c}\text { Administrative } \\
\text { Expenditures } \\
\text { (current Taka) }\end{array}$ & $\begin{array}{c}\text { Total } \\
\text { Extension } \\
\text { Expenditures } \\
\text { (current Taka) }\end{array}$ & $\begin{array}{c}\text { Input } \\
\text { cost change } \\
\text { (current Taka) }\end{array}$ & $\begin{array}{c}\text { Total } \\
\text { Expenditures } \\
\text { (current Taka) }\end{array}$ & $\begin{array}{c}\text { Total } \\
\text { (2007-08 Tk.) }\end{array}$ \\
\hline $1980-81$ & 125000 & 124550 & 0 & 0 & 249550 & 1475139 \\
$1981-82$ & 425000 & 133000 & 0 & 0 & 558000 & 2854002 \\
$1982-83$ & 235000 & 141900 & 0 & 0 & 376900 & 1753902 \\
$1983-84$ & 200000 & 885500 & 0 & 0 & 1085500 & 4599356 \\
$1984-85$ & 112500 & 818050 & 0 & 0 & 930550 & 3567626 \\
$1985-86$ & 164250 & 634100 & 220309 & 281200 & 1299859 & 4485540 \\
$1986-87$ & 174350 & 956650 & 1026029 & 635364 & 2792393 & 8630861 \\
$1987-88$ & 187300 & 539250 & 1134000 & 1334500 & 3195050 & 9064153 \\
$1988-89$ & 177950 & 562700 & 1284993 & 2084397 & 4110040 & 10811807 \\
$1989-90$ & 284450 & 819500 & 1291320 & 2676577 & 5071847 & 12305861 \\
$1990-91$ & 635100 & 746050 & 1684024 & 4045322 & 7110496 & 15892219 \\
$1991-92$ & 755700 & 1107250 & 1767249 & 5555559 & 9185758 & 19550597 \\
$1992-93$ & 1630450 & 1346100 & 1828555 & 7160137 & 11965242 & 25244078 \\
$1993-94$ & 2741150 & 798650 & 2199600 & 9512245 & 15251645 & 31216936 \\
$1994-95$ & 660000 & 225500 & 2317525 & 9992339 & 13195364 & 25648035 \\
$1995-96$ & 1980000 & 171400 & 2238367 & 11681879 & 16071645 & 29921794 \\
$1996-97$ & 7788000 & 261250 & 2408661 & 14163300 & 24621211 & 45035932 \\
$1997-98$ & 8699064 & 675850 & 2660407 & 15545425 & 27580746 & 48295222 \\
$1998-99$ & 2882220 & 1181750 & 2806472 & 17504089 & 24374531 & 40648556 \\
$1999-00$ & 1728804 & 1221000 & 3312387 & 20846439 & 27108630 & 43055350 \\
$2000-01$ & 2132064 & 1114500 & 3354363 & 25919017 & 32519944 & 48889658 \\
$2001-02$ & 1985280 & 645000 & 3424078 & 30110662 & 36165019 & 51292050 \\
$2002-03$ & 3334320 & 173500 & 3592067 & 33461606 & 40561493 & 54271199 \\
$2003-04$ & 3859020 & 271300 & 4216270 & 46743229 & 55089818 & 69537802 \\
$2004-05$ & 14129808 & 301300 & 4854348 & 53006990 & 72292446 & 86086822 \\
$2005-06$ & 13091496 & 442200 & 5433602 & 64197231 & 83164529 & 93427779 \\
$2006-07$ & 11586960 & 724950 & 6909080 & 71413783 & 90634773 & 96056526 \\
$2007-08$ & 14171520 & 690350 & 7058884 & 82165158 & 104085911 & 104085911 \\
\hline Total & 95876756 & 17713100 & 67022590 & 530036448 & 710648890 & 987704713 \\
\hline
\end{tabular}

Note: $\$ 1.00=$ Tk. 80.00

Table 6. Estimation of surplus from turmeric research and extension investments

\begin{tabular}{|c|c|c|c|c|c|}
\hline Year & $\begin{array}{l}\text { Change in } \\
\text { consumer } \\
\text { surplus (Tk.) }\end{array}$ & $\begin{array}{c}\text { Change in } \\
\text { producer surplus } \\
\text { (Tk.) }\end{array}$ & $\begin{array}{l}\text { Change in total } \\
\text { surplus (Tk.) }\end{array}$ & $\begin{array}{l}\text { Total expenditure } \\
\text { (Based on 2007-08 } \\
\text { Tk.) }\end{array}$ & Net Benefit (Tk.) \\
\hline A & $\mathrm{B}$ & $\mathrm{C}$ & $\mathrm{D}=\mathrm{B}+\mathrm{C}$ & $\mathrm{E}$ & $\mathrm{F}=\mathrm{D}-\mathrm{E}$ \\
\hline $1980-81$ & 0 & 0 & 0 & 1475139 & -1475139 \\
\hline 1981-82 & 0 & 0 & 0 & 2854002 & -2854002 \\
\hline $1982-83$ & 0 & 0 & 0 & 1753902 & -1753902 \\
\hline 1983-84 & 0 & 0 & 0 & 4599356 & -4599356 \\
\hline 1984-85 & 0 & 0 & 0 & 3567626 & -3567626 \\
\hline $1985-86$ & 0.14 & 12567323.59 & 12567323.72 & 4485540 & 8081784 \\
\hline 1986-87 & 0.20 & 18699643.14 & 18699643.35 & 8630861 & 10068782 \\
\hline 1987-88 & 0.39 & 35892454.42 & 35892454.81 & 9064153 & 26828302 \\
\hline 1988-89 & 0.59 & 54539682.00 & 54539682.59 & 10811807 & 43727876 \\
\hline 1989-90 & 0.83 & 76900261.89 & 76900262.72 & 12305861 & 64594402 \\
\hline 1990-91 & 1.49 & 139643807.17 & 139643808.67 & 15892219 & 123751590 \\
\hline $1991-92$ & 1.87 & 176522118.24 & 176522120.11 & 19550597 & 156971524 \\
\hline 1992-93 & 2.31 & 219729031.58 & 219729033.89 & 25244078 & 194484956 \\
\hline 1993-94 & 2.63 & 252430504.29 & 252430506.92 & 31216936 & 221213571 \\
\hline $1994-95$ & 1.93 & 185271298.96 & 185271300.88 & 25648035 & 159623266 \\
\hline $1995-96$ & 2.06 & 198973912.42 & 198973914.48 & 29921794 & 169052120 \\
\hline 1996-97 & 3.49 & 340896087.72 & 340896091.21 & 45035932 & 295860160 \\
\hline $1997-98$ & 4.70 & 460210029.27 & 460210033.97 & 48295222 & 411914812 \\
\hline 1998-99 & 5.00 & 492267151.11 & 492267156.11 & 40648556 & 451618600 \\
\hline 1999-00 & 5.40 & 538506185.99 & 538506191.39 & 43055350 & 495450841 \\
\hline 2000-01 & 4.29 & 434278640.51 & 434278644.80 & 48889658 & 385388987 \\
\hline 2001-02 & 3.49 & 358382061.88 & 358382065.37 & 51292050 & 307090016 \\
\hline 2002-03 & 3.59 & 370955714.75 & 370955718.34 & 54271199 & 316684519 \\
\hline 2003-04 & 8.45 & 892087989.68 & 892087998.12 & 69537802 & 822550196 \\
\hline 2004-05 & 10.59 & 1130017034.46 & 1130017045.05 & 86086822 & 1043930223 \\
\hline 2005-06 & 12.18 & 1316432587.41 & 1316432599.59 & 93427779 & 1223004821 \\
\hline $2006-07$ & 10.52 & 1138926169.57 & 1138926180.09 & 96056526 & 1042869654 \\
\hline 2007-08 & 13.50 & 1477455192.84 & 1477455206.34 & 104085911 & 1373369295 \\
\hline Total & 99.64 & 10321584882.89 & 10321584982.52 & 987704713 & 9333880272 \\
\hline
\end{tabular}

Note: $\$ 100=$ Tk. 80.00 
The total over years changes in consumers' and producer' surplus were estimated Tk. 99.64 and Tk. 10321.58 million respectively from turmeric research and extension. Consumers' surplus was very much lower compared to producers' surplus due to perfectly elasticity of demand for turmeric in the small-open economy market. The estimated total surplus/ total benefits ranged from Tk. 12.57 million in 1985-86 to 1477.46 million in 2007-08 and the total surplus accrued as Tk. 10321.58 million from the turmeric research and extension in Bangladesh. Besides, the total net benefits obtained from turmeric research and extension was Tk. 9333.88 million for the year 1980-81 to 2007-08 (Table 6).

\section{Rate of return to turmeric research and extension}

The rates of returns are the indicators which help to estimate the investment efficiency of the research programme. There are many types of measures that can be used to estimate the rates of return. Among them, Net Present Value (NPV) of benefit, External Rare of Return (ERR) and Internal Rate of Return (IRR) was considered as the rates of return to turmeric research and extension investments in Bangladesh. For comparing the net benefits with the total research costs, Present Value of Research Costs (PVRC) was also calculated. All the estimates were calculated at constant (2007-08) prices with $10 \%$ discount rate. Table 7 was used to calculate the NPV, PVRC, ERR, IRR and BCR under small- open economy condition. Under open economy, the producers' benefits were found much higher compared to consumers' benefits since the elasticity of demand for turmeric were very high.

Table 7 revealed that the society was benefited substantially from the investment in spices research and extension in Bangladesh. The NPV of benefit indicates the total social benefit for a country and it was found negative up to 1984-85 and then it was positive. It means that the country did not receive any benefit from turmeric research up to 1984-85 (Table 6). After 1984-85, the country as a whole benefited with a big amount and found increasing trend up to 2007-08. The NPV was found to be Tk. 1200.84 million while PVRC over the period was Tk. 157.88 million for turmeric research and extension investment. The ERR was found to be $1049.50 \%$. This means that the average taka spent on research and extension in turmeric earn return $10 \%$ annually from the start of the initial investment (1980-81) and is now paying off at the rate of $1049.50 \%$ annually into perpetuity. In the benefit/cost mode, using $10 \%$ external interest rate, a one taka investment returned 104.95 taka over the period. The IRR of $68 \%$ means that on the average, each taka invested in turmeric research and extension returned 68\% annually from the date of the initial investment. It implies that the expenditure on turmeric research and extension (Tk. 157.88 million) could have been borrowed at $68 \%$ real rate of interest without incurring loss (Table 7).

Table 7. Estimated rates of returns to turmeric research and extension

\begin{tabular}{l|c|c|c|c|c}
\hline \multirow{2}{*}{$\begin{array}{l}\text { Name of } \\
\text { crop }\end{array}$} & $\begin{array}{c}\text { Net present value } \\
\text { (NPV) }\end{array}$ & $\begin{array}{c}\text { Present value of } \\
\text { research cost } \\
\text { (PVRC) }\end{array}$ & $\begin{array}{c}\text { External Rate of } \\
\text { Return (ERR) }\end{array}$ & $\begin{array}{c}\text { Internal Rate of } \\
\text { Return (IRR) }\end{array}$ & $\begin{array}{c}\text { Benefit Cost } \\
\text { Ratio (BCR) }\end{array}$ \\
\cline { 2 - 5 } & \multicolumn{2}{|c|}{ Million taka in 2007-08 constant prices } & & \\
\hline Turmeric & 1200.84 & 157.88 & 1049.50 & 68 & 10.45 \\
\hline
\end{tabular}

Note: $\$ 1.00=$ Tk. 80.00

The benefit cost ratios were found to be 10.45 for turmeric. The value of the parameter clearly indicated that the investment in research and extension of turmeric in Bangladesh is a good investment and highly profitable.

\section{Foreign exchange savings}

The yearly increase in production due to research save the country's foreign exchange to a remarkable extends. First, the research induced productions for turmeric for the past years were calculated by multiplying the country's total turmeric production by their respective production function shifter $\mathrm{k}$. Multiplying the results by world turmeric price, foreign exchange savings was obtained.

Considerable amounts of turmeric are imported in Bangladesh every year to meet the internal demand for increasing population. In 2006/07, the imported value of turmeric was Tk. 148.70 million (BBS 2008). In reality, the amount imported is higher due to the illegal border trade of spices from neighbouring countries. Thus, the increased production attributed to turmeric improvement saved foreign exchange amounting to Tk. 9084.63 million from turmeric research and extension (Table 8). 
Table 8. Foreign exchange savings from investment in turmeric research

\begin{tabular}{l|c|c|c|c|c}
\hline Year & $\begin{array}{c}\text { Import (cif) } \\
\text { Price } \\
\text { (Taka) }\end{array}$ & $\begin{array}{c}\text { Supply } \\
\text { Shifter } \\
\text { K (per cent) }\end{array}$ & $\begin{array}{c}\text { Turmeric } \\
\text { Production } \\
\text { (ton) }\end{array}$ & $\begin{array}{c}\text { Increase in } \\
\text { Production from } \\
\text { Research (ton) }\end{array}$ & $\begin{array}{c}\text { Foreign Exchange } \\
\text { Savings (Taka) }\end{array}$ \\
\cline { 2 - 5 } & 1 & 2 & 3 & $4=2 \times 3$ & $5=1 \times 4$ \\
\hline $1986-87$ & 152500 & 0.0099 & 34665 & 343.13 & 52326879 \\
$1987-88$ & 98540 & 0.0197 & 34740 & 686.00 & 1003.14 \\
$1988-89$ & 58998 & 0.0279 & 35928 & 1278.57 & 59183308 \\
$1989-90$ & 19455 & 0.0337 & 37925 & 1915.49 & 24874717 \\
$1990-91$ & 20564 & 0.0494 & 38780 & 2604.02 & 39390074 \\
$1991-92$ & 36713 & 0.0633 & 41115 & 3251.77 & 95602759 \\
$1992-93$ & 39686 & 0.0790 & 41170 & 4145.54 & 129049292 \\
$1993-94$ & 41083 & 0.0987 & 41990 & 3971.42 & 163285631 \\
$1994-95$ & 41115 & 0.1004 & 39550 & 4476.18 & 188416125 \\
$1995-96$ & 42093 & 0.1103 & 40580 & 5236.54 & 191571573 \\
$1996-97$ & 36584 & 0.1243 & 42140 & 5326.49 & 195858544 \\
$1997-98$ & 36771 & 0.1283 & 41500 & 5645.77 & 197960223 \\
$1998-99$ & 35063 & 0.1382 & 40850 & 6520.30 & 228388340 \\
$1999-00$ & 35027 & 0.1595 & 40875 & 8004.13 & 264734501 \\
$2000-01$ & 33075 & 0.1866 & 42900 & 8897.47 & 362019408 \\
$2001-02$ & 40688 & 0.2087 & 42640 & 9570.80 & 362878682 \\
$2002-03$ & 37915 & 0.2184 & 43820 & 17878.51 & 744444648 \\
$2003-04$ & 41639 & 0.2528 & 70730 & 21305.47 & 1025660930 \\
$2004-05$ & 48141 & 0.2691 & 79175 & 26735.56 & 1324687145 \\
$2005-06$ & 49548 & 0.2894 & 92395 & 32107.60 & 1663787020 \\
$2006-07$ & 51819 & 0.2919 & 110000 & 36009.14 & 1532602974 \\
$2007-08$ & 42561 & 0.3082 & 116832 & Tk. & 9084632260 \\
\hline
\end{tabular}

Note: $\$ 100=$ Tk. 80.00

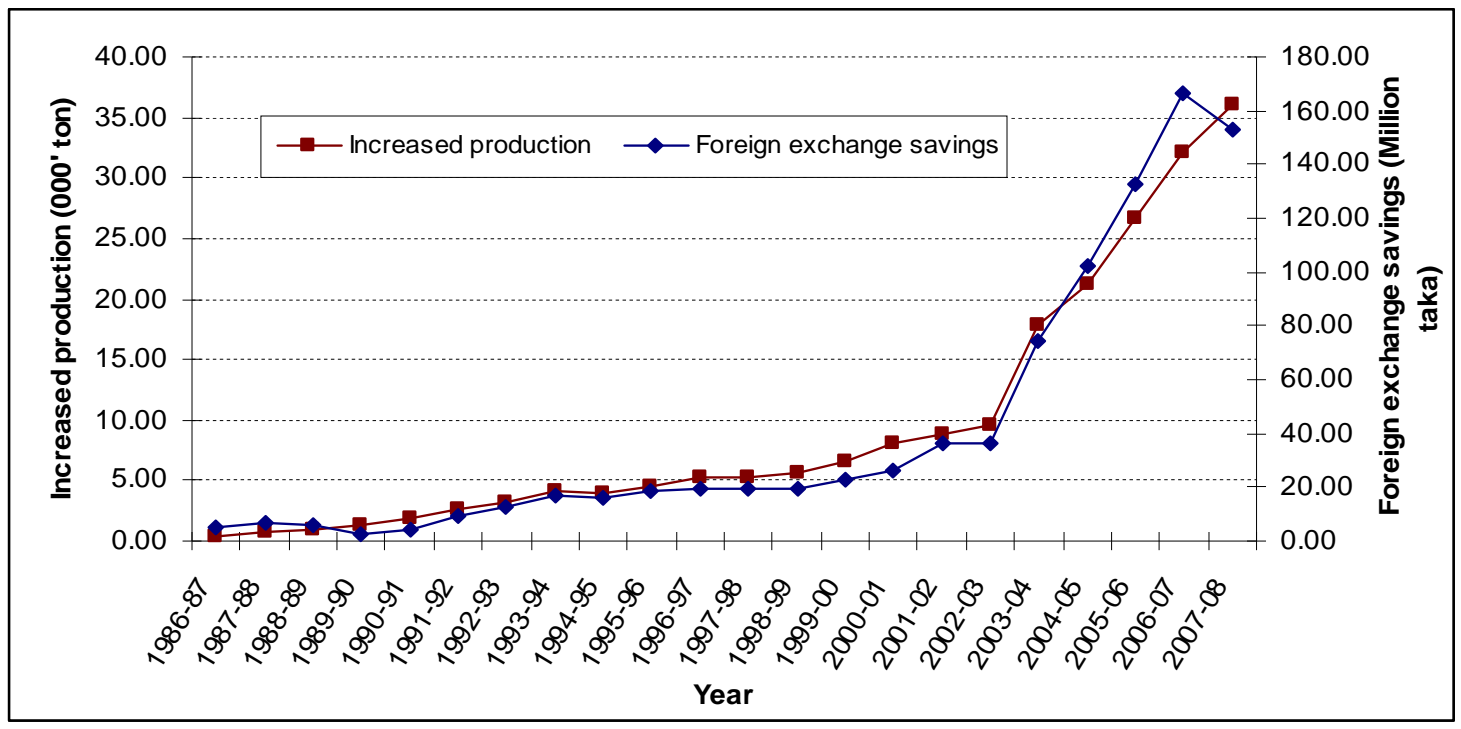

Fig. 3. Foreign exchange savings due to turmeric research and development over time

\section{Policy implications}

The empirical results indicate that the expenditure on turmeric research and development paid a favourable rate of returns and the society were also benefited enormously out of it. The IRR to turmeric research and development expenditure was found to be $68 \%$. A $68 \%$ IRR on investment in turmeric research and development is a good rate of return. The consumer's surplus is found to be very few only due to small open economy. But this situation might not be the good sign for the economic prosperity. For the survival of the consumer, price support should be given by government.

The annual adoption rates of BARI Turmeric-1, 2 and 3 are not good because of non availability of seed. Seed production programme should be taken largely by the government and nongovernmental organization so that the farmers can get quality seed easily with a reasonable price. 


\section{References}

Akino, M. and Hayami, Y. 1975. Efficiency and Equity in Public Research: Rice Breeding in Japan's Economic Development. American J. Agril. Econ. 57: 1-10.

Alston, J.M., Norton, G.W. and Pardey, P.G. 1995. Since Under Scarcity: Principles and Practice for Agricultural Research. Evaluation and Priority Setting. Cornell University Press Ithaka. p. 237.

Ayer, H.W. and Schuh, G.E. 1972. Social Rates of Return and Other Aspects of Agricultural Research: The Case of Cotton Research in Sao Paulo, Brazil. American J. Agril. Econ. 54: 557-569.

BBS. 2008. Statistical Year Book of Bangladesh Bureau of Statistics Ministry of Planning Government of the People's Republic of Bangladesh Dhaka.

BBS. 2012. Statistical Year Book of Bangladesh Bureau of Statistics Ministry of Planning Government of the People's Republic of Bangladesh Dhaka.

Currie, J.M., Murphy, J .A. and Schmitz, A. 1971. The Concept of Economic Surplus and Its Use in Economic Analysis. Econ. J. 18: 741798.

Dey, M. and Norton, G. 1993. Analysis of Agricultural Research Priorities in Bangladesh. BARC, ISNAR. p. 300.

Gardiner, J.C., Sanders, J.H. and Barker, T.G. 1986. An Economic Evaluation of the Prude Soft Red Winter Wheat Programme. Department of Agricultural Economics,
Agricultural Experimental Station, Prude University, West Lfayette. p. 258.

Hertford, R. and Schmitz, A. 1971. Measuring Economic Returns to Agricultural Research. Resource Allocation and Productivity in National and International Agricultural Research. Minneapolis. University of Minnesota Press. pp. 148-167.

Nagy, J.G. 1991. Returns from Agricultural Research and Extension in Wheat and Maize in Pakistan. Research and Productivity in Asian Agriculture. Cornell University Press. Ithaca. New York.

Nagy, J .G. and Alam, M.F. 2000. The Impact of Agricultural Research in Bangladesh: Estimating Returns to Agricultural Research. Project Report, BARC, Dhaka and International Fertilizer Development Centre, Muscle Shoals, Alabama.

Nagy, J.G. and Furtan, W.H. 1978. Economic Cost and Returns from Crop Development Research: The Case of Rapeseed Breeding in Canada. Canadian J. Agril. Econ. 26 (1): 114.

Peterson, W.L. 1971. The Returns to Investment in Agricultural Research in the United States. In: W.L. Fishel, ed., Resources Allocation in Agricultural Research.

Scobie, G.M. and Posada, R.T. 1977. The Impact of High Yielding Rice Varieties in Latin America-with Special Emphasis on Colombia. Series JE-01. CIAT. Calli. Colombia. 